\title{
CHARACTERIZATION OF SOILS IN THE ALMASU MARE AREA THROUGH THE DETERMINATION OF LEAD CONCENTRATIONS
}

\author{
ADRIANA MIHAELA CHIRILĂ BĂBĂU ${ }^{a *}$, VALER MICLE ${ }^{a}$, \\ IOANA MONICA SUR ${ }^{a}$
}

\begin{abstract}
The present study consisted in the determination of lead concentrations in soil samples and sterile material dumped collected from the Almașu Mare mining area. The lead concentration in the samples collected were determined by atomic adsorption spectrometry (AAS). In spite of the fact that all mines from area are nowadays inactive, the results of the chemical analysis showed that the soils in the area are still highly polluted with lead, except at the base of the "Radeș" dump, where the lead concentrations were below the intervention thresholds.
\end{abstract}

Keywords: mining area, "Radeş" dump, lead concentration.

\section{INTRODUCTION}

In the very beginning the curiosity and interest of researchers was probably devoted to herbs which were able to grow on heavy metals contaminated soils, restricting metals uptake or accumulating them in their tissues [1-7]. Sterile dumps are detrimental to natural plant growth due to their physicochemical characteristics, such as low $\mathrm{pH}$, high heavy metal concentrations, deficiencies in soil organic matter and low fertility. Thus, the remediation of sterile dumps has become a key issue in environmental science.

High concentrations of lead in soils are associated with long-term pollution $[4,5]$. Lead has been known to be toxic since the 2nd century BC in ancient Greece. Lead is one of the most common contaminants found in soils. It is toxic both to humans and animals, especially to young children [6].

\footnotetext{
a Technical University of Cluj-Napoca, Faculty of Materials and Environmental Engineering, Department of Environmental Engineering and Sustainable Development Entrepreneurship, 103-105 Muncii Ave, Cluj Napoca, Romania,

*Corresponding author: adriana.babau@yahoo.com
} 
Where the soil is acid $\mathrm{Pb}$ is mobile and is available for uptake by plants, but the effect of $\mathrm{pH}$ on $\mathrm{Pb}$ availability is not large $[8,9]$.

Current remediation of $\mathrm{Pb}$ contaminated soils by stabilization/ solidification (immobilization) technique is in the development stage [6].

The phytoremediation contaminated soil with lead, using plants, also is a technology in development. Phytoremediation is a concept that has been in use since the early 1990 and is composed of a set of natural technologies that use plants to clean up contaminated areas. This technology has become in the last period a great money saver and its applications can contribute with great success at cleaning up and healing the contaminated soils [2]. The researchers suggest that this technology will be economically feasible only if systems can be developed to employ high biomass plants that can accumulate greater than $1 \% \mathrm{~Pb}$ in their shoots [10]. Phytoremediation, an in situ cost-effective and friendly technology, is emerging as the most promising remediation method for mine tailings by introducing tolerant plant species [3].

\section{The possibility of applying phytoremediation technology to lead-polluted soils}

The technologies of phytoremediation are based on different mechanisms which include: phytoextraction, phytostabilization, phytoevaporation, rhizofiltration and rhizodegradation. The primary attention is given to the phytoextraction and phytostabilization as the most widespread and alternative methods of soil remediation.

Phytoextraction (also known as phytoaccumulation or phytoabsorption) is the uptake of contaminants from soil by plant roots and their translocation and accumulation in above ground biomass and shoot [11] and the phytostabilization is the immobilization of contaminants through absorption by roots, precipitation, complexation or metal valence reduction in rhizosphere. In this case, the plants are used to limit the mobility and bioavailability of pollutions in the environment and to prevent the contaminant migration caused by wind and water erosion [2].

In order to know which plant is best for phytoremediation it is very important to determine the concentrations of heavy metal from soil and from the parts of the plant. These data are employed in the determination of the bioaccumulation and the translocation factor which indicate the plant's capacity to remediate a contaminated soil by phytoextraction and phytostabilization. The bioaccumulation factor (BAF) is defined as the total element concentration in shoot tissue/total element concentration in mine tailings [1]. $\mathrm{Pb}$ bioaccumulation from shoot and soil can be calculated by the equation (1)[13]:

$$
\mathrm{BAF}=\mathrm{C}_{\text {shoot }} / \mathrm{C}_{\text {soil }}
$$


where: $\mathrm{C}_{\text {shoot }}$ and $\mathrm{C}_{\text {soil }}$ are metal concentration in the plant shoot $\left(\mathrm{mg} / \mathrm{kg}^{-1}\right)$ and soil $\left(\mathrm{mg} / \mathrm{kg}^{-1}\right)$, respectively. BAF was categorized further as hyperaccumulators, accumulator and excluder to those samples which accumulated metals $>1$ $\mathrm{mg} / \mathrm{kg}^{-1}$, and $<1$, respectively $[13,14,15]$.

The translocation factor (TF) or shoot/root (S/R) ratio is defined as the total element concentration in shoot tissue/total element concentration in root tissue [12]. Pb translocation from shoot to root can be measured by the equation (2),[13]:

$$
\mathrm{TF}=\mathrm{C}_{\text {shoot }} / \mathrm{C}_{\text {root }}
$$

where: $\mathrm{C}_{\text {shoot }}$ and $\mathrm{C}_{\text {root }}$ are metals concentration in the shoot $\left(\mathrm{mg} / \mathrm{kg}^{-1}\right)$ and root of plant $\left(\mathrm{mg} / \mathrm{kg}^{-1}\right)$, respectively. TF>1 represent that translocation of metals effectively was made to the shoot from root $[13,14,16,17,18]$.

Plants with both factors $>1$ are suitable for phytoextraction while, plants with both factors $<1$ are suitable for phytostabilization [1].

The immobilization of lead was tested in experiments using different additives (lime, activated carbon, clay, zeolite, sand and cement) and artificially lead contaminated soil samples, according to the Toxicity Characterization Leaching Procedure (TCLP) developed by U.S. EPA [6]. Results showed that, activated carbon, clay, zeolite and sand are not very efficient for $\mathrm{Pb}$ immobilization. Lime and cement are significantly effective in $\mathrm{Pb}$ immobilization with $88 \%$ efficiency at 1:21 lime: soil ratio and 99\% efficiency at 1:15 cement: soil ratio.

Otherwise, besides the importance of choosing the most suitable plant in phytoremediation, it has been found that another important aspect in the bioaccumulation of heavy metals from the soil in the plant is the addition of inorganic and organic substances. Microorganisms release $\mathrm{CO}_{2}$ during their metabolism, which solubilize in soil water as $\mathrm{HCO}_{3}{ }^{-}$which produces $\mathrm{CaCO}_{3}$ at high $\mathrm{pH}$ in presence of $\mathrm{Ca}^{2+}[19]$. Precipitation of $\mathrm{CaCO}_{3}$ can be enhanced by the addition of organic compounds rich in nitrogen because the microorganisms hydrolyze urea leading to the production of $\mathrm{CO}_{3}{ }^{2-}$ at neutral/basic $\mathrm{pH}[20]$.

Thus, in order to improve the bioaccumulation and translocation of heavy metals from soil in plants, it is important to contribute to soil quality and fertility, lowering the mobility of metals and accelerating plant growth [21]. Numerous studies have shown that the plants of the Acacia family can be used successfully in phytostabilization of degraded lands, being a good ground fixer [22].

The aim of this paper was to determine the lead concentration from soil and sterile material samples collected from Almașu Mare mining area in order to apply the most suitable technique of phytoremediation. 


\section{RESULTS AND DISCUSSION}

Lead concentrations determined from soil samples were compared with the intervention thresholds established by the Romanian legislation [24]. The variation of lead concentration from the soil and sterile material samples taken from mining perimeter studied are highlighted in the figure 1, 2 and 3. The results obtained at the determination of the lead concentration of the sterile material samples taken from the three particular points are shown in Figure 1.

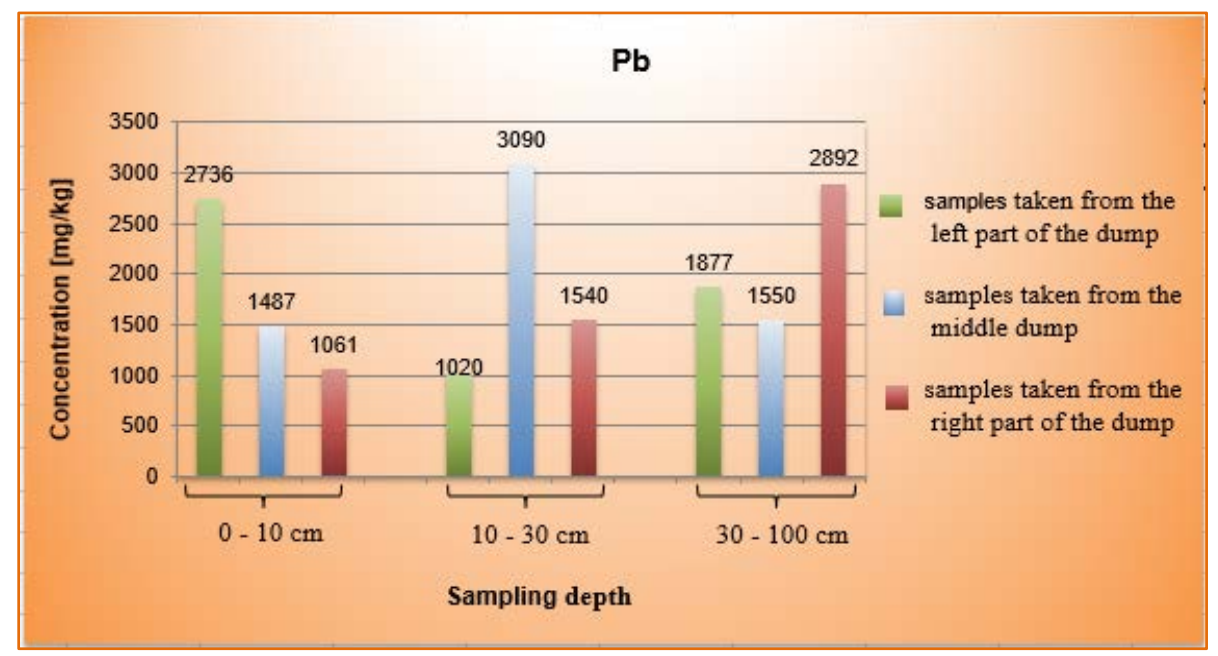

Figure 1. Lead concentrations present in samples taken from the surface of the "Radeș" dump

The analyzes performed on samples of sterile material collected from the left side of the "Radeș" dump showed that the $\mathrm{Pb}$ concentration on the first sampling layer $(0-10 \mathrm{~cm})$ was $2736 \mathrm{mg} / \mathrm{kg}$, decreasing to a depth of 10-30 $\mathrm{cm}$ to $1020 \mathrm{mg} / \mathrm{kg}$, and the third sampling layer $(30-100 \mathrm{~cm}$ ) increased to 1877 $\mathrm{mg} / \mathrm{kg}$. In the middle part of the dump, the $\mathrm{Pb}$ concentration was $1487 \mathrm{mg} / \mathrm{kg}$ on the first sampling layer, increased to $3090 \mathrm{mg} / \mathrm{kg}$ at 10-30 cm depth and the third sampling layer $(30-100 \mathrm{~cm})$ decreased again to $1550 \mathrm{mg} / \mathrm{kg}$.

On the right side of the dump the lead concentration increased with the depth. The value at the depth of 0-10 cm was $1061 \mathrm{mg} / \mathrm{kg} 1540 \mathrm{mg} / \mathrm{kg}$ in the depth of $10-30 \mathrm{~cm}$, and $2892 \mathrm{mg} / \mathrm{kg}$ at the depth of $30-100 \mathrm{~cm}$.

The lead concentrations at the base of the dump are shown in Figure 2. 
CHARACTERIZATION OF SOILS IN THE ALMASU MARE AREA THROUGH THE ...

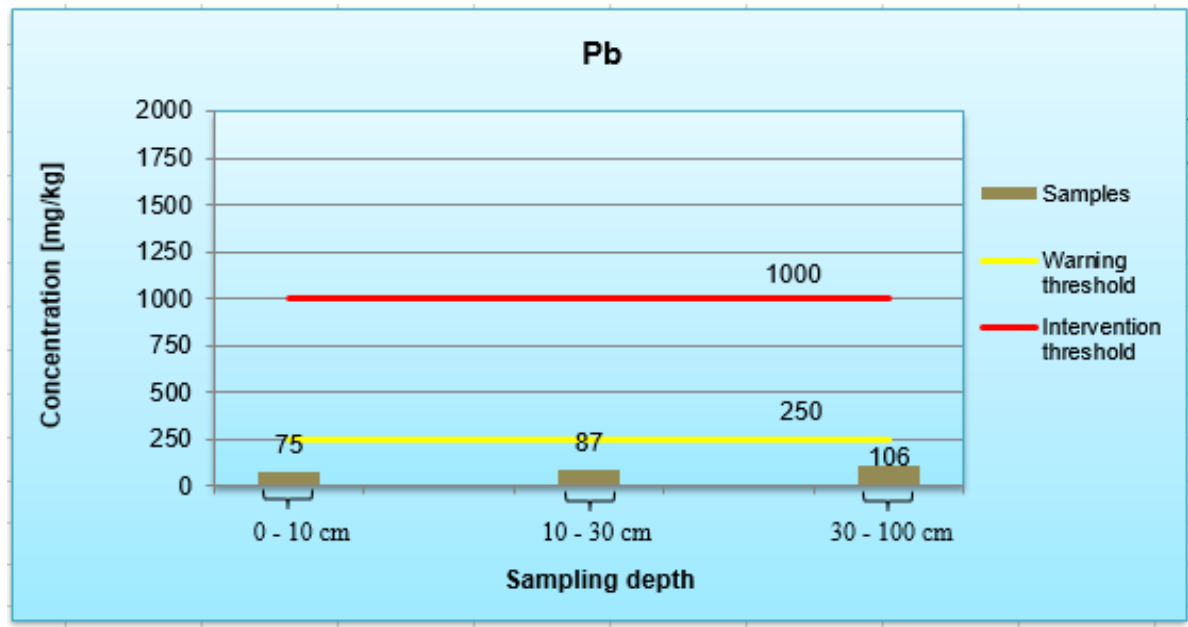

Figure 2. Lead concentrations present in samples taken at the base of the "Radeş" dump

At the base of the dump, the concentrations of $\mathrm{Pb}$ measured from the samples taken does not exceed the alert and intervention threshold. the dump.

Figure 3 highlights $\mathrm{Pb}$ concentrations upstream and downstream of

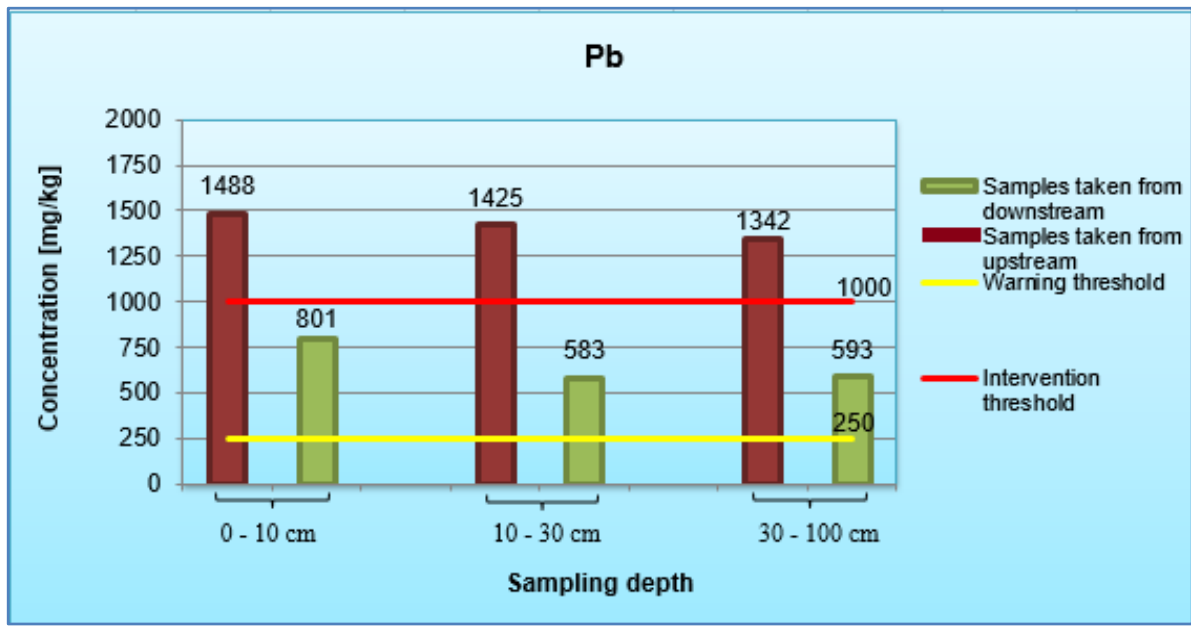

Figure 3. Lead concentrations present in samples taken from upstream and downstream of the "Radeș" dump 
Upstream from the sources of pollution in the Almaşu Mare area, lead concentrations decrease with the depth and exceed the alert threshold of more than 4 times and the threshold for intervention at all sampling depths.

Downstream, $\mathrm{Pb}$ concentrations have fallen above the alert threshold, but are slightly lower compared to concentrations upstream from sterile dump.

\section{CONCLUSIONS}

The sterile dumps are considered to widespread contamination of the environment. On the surface of the "Rades" dump the lead concentrations resulted from the analysis performed showed values ranging from 1020 $3090 \mathrm{mg} / \mathrm{kg}$. At the base of the dump, the $\mathrm{Pb}$ concentrations measured did not exceed the intervention threshold. Upstream and downstream of the "Radeş" dump, $\mathrm{Pb}$ concentrations exceeded the intervention thresholds at all sampling depths. In this area it is necessary to apply remediation methods.

The most suitable phytoremediation technique that can be applied to the sterile dumps in the studied area is phytostabilisation. Robinia Pseudoacacia is suitable for use in phytostabilization of polluted soils because it has the capacity to absorb and agglomerate $\mathrm{Pb}$ concentrations in roots and around it.

\section{EXPERIMENTAL SECTION}

\section{Study area}

The investigation site is located in the Almaşu Mare village, in the southern outskirts of the Apuseni Mountains from Romania, in the subunit of Metaliferi Mountains, bordering the town Zlatna and Alba County [23]. The total area of this village is 9330 ha. Since 1900, in this area were performed mining activities which are making their presence felt even today through the enormous quantities of mining waste deposited inappropriately and through the waste water which flows into the rivers due to rainfall over them. The "Radeș" sterile dump is located in Almasu Mare village (Figure 4) and stretches over a distance of $100 \mathrm{~m}$, with a height of $30 \mathrm{~m}$. In the front of dump, at $50 \mathrm{~m}$ away is "Radeş" mine and at $5 \mathrm{~m}$ distance is the Ardeu stream that flows into the Ampoi River.

This dump is not subject to conservation or reforestation process, it being still below the target mining strategy for the period 2008-2020 which aims to restore the environment affected by mining. The people and their households are very close to this dump at no $2 \mathrm{~m}$ from it. This fact this represents a source of risk and negative impact on human health [25]. 


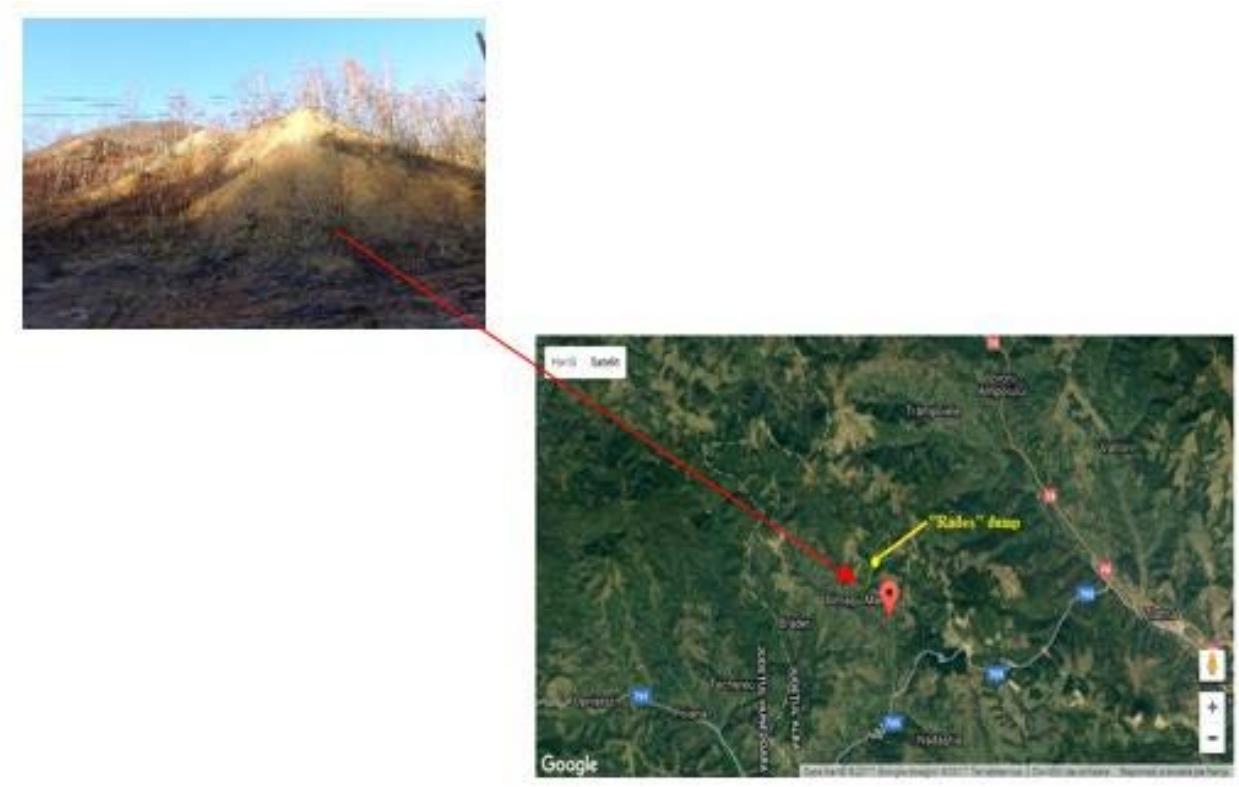

Figure 4. The image of the study area

\section{Sampling and analyzing}

In order to evaluate the quality of soil in the Almașu Mare mining area were collected nine samples of soil and waste material from three different points (the dump "Radeș", upstream dump and downstream of it) at the following depths: 0-10 cm, $10-30 \mathrm{~cm}$ and $30-100 \mathrm{~cm}$.

Soil sampling was performed in November, 2016 and analysis of heavy metals concentrations from samples was performed in the Laboratory of soil quality analysis and depollution processes at the Technical University of Cluj Napoca by Atomic Absorption Spectrometry (AAS) using a SHIMADZU AA-6800 spectrometer.

The preparation of samples for analysis consisted of the following: the moist soil and sterile material was crumbled, dried at $40{ }^{\circ} \mathrm{C}$, sieved and milled. Prior analyzing heavy metal content, $3 \mathrm{~g}$ of prepared samples were placed in a 100 beaker with $21 \mathrm{ml}$ of $\mathrm{HCl}$ concentrated and $7 \mathrm{ml}$ of $\mathrm{HNO}_{3}$ concentrated. Then, the glasses were covered with glass plate and left for mineralization. After these, samples were filtered and analyzed for heavy metal content. Reference solutions for calibration, were also prepared using analytical grade chemicals and deionized water. 


\section{ACKNOWLEDGMENTS}

The authors gratefully acknowledge the financial support provided by the Romanian National Authority for Scientific Research, CNCS - UEFISCDI, under grant no. PN-II-PT-PCCA-2013-4-1717.

\section{REFERENCES}

1. A. Buscaroli, Ecological Indicators, 2017, 82, 367.

2. M. Boroș, V. Micle, Scientific Papers. Series E. Land Reclamation, Earth Observation \& Surveying, Environmental Engineering, 2014, Vol. III, 2285.

3. L. Wang, B. Ji, Y. Hu, R. Liu, W. Sun, Chemosphere, 2017, Vol.184, 594.

4. I.M. Sur, V. Micle, T. Gabor, Studia UBB Chemia, 2016, LXI, 3 (2), 364.

5. V. Farkas, A. Hegedüsova, S. Jakabova, C. Majdik, T. Pernyeszi, Studia UBB Chemia, 2011, 56(2), 65.

6. B. Alpaslan, M. Ali Yukselen, Water, Air and Soil Pollution, 2002, 133(1-4), 253.

7. G.A. Seilkhanova, A N. Imangaliyeva, D.N. Akbayeva, Z.Z. Kenzhalina, Studia UBB Chemia, 2017, 62(1), 35.

8. E.B. Culbard, I. Thornton, J. Watt, M. Wheatley, S. Moorcroft, M. Thompson, Journal of Environmental Quality, 1988,17, 226.

9. J. Watt, I. Thornton, J. Cotter-Howells, Applied Geochemistry, Supplementary, 1993, 2, 269.

10. A.A. Juwarkar, A. Nair, K.V. Dubey, S.K. Singh, S. Devotta, Chemosphere, 2017, 68(10), 1996.

11. A. Mahar, P. Wang, A. Ali, M. K. Awasthi, A.H. Lahori, Q. Wang, R. Li, Z. Zhang, Ecotoxicology and Environmental Safety, 2016, 126, 111.

12. R.R. Brooks, Microbiology, Archaeology, Mineral Exploration and Phytomining. $C A B$ International, Wallingford, Oxford, UK, 1998, 384.

13. M. Rezvani, F. Zaefarian, Australian Journal of Agricultural Engineering, 2011, 2(4), 114.

14. L.Q. Ma, K.M. Komar, C. Tu, W. Zhang, T. Cai, E.D. Kenelly, Nature, 2001, 409, 579.

15. C. Cluis, Biotech J., 2004, 2, 60.

16. A.J.M. Baker, R.R. Brooks, Biorecovery, 1989, 1, 81.

17. W.H. Zhang, Y Cai, C. Tu, Q.L. Ma, Science of the Total Environment, 2002, 300, 167.

18. A.Q. Fayiga, L.Q. Ma, Science of the Total Environment, 2006, 359, 17.

19. J.M. Arocena, V.J.M. Mourik, A. Faz-Cano. Canadian Journal of Soil Science, 2012, Vol. 92, 243.

20. K. Rowshanbakht, M. Khamehchiyan, R.H Sajedi, M.E. Nikudel, Ecological Engineering, 2016, Vol. 89, 49. 
21. R. Zornoza, M. Gómez-Garrido, S. Martínez-Martínez, M. Dolores, G. López, Á. Faz, Science of the Total Environment, 2017, Vol. 593 - 594, 357.

22. R. Budău, I. A. Timofte, N. Kopacz, Annals of the University of Oradea, Faculty of Environmental Protection, 2014, Vol. XXIII, 337.

23. S. Varvara, M. Popa, R. Bostan, G. Damian, Journal of Environmental Protection and Ecology, 2013, 14 (4), 1506.

24. ORDER 756/1997 published in Monitorul Oficial 303 from 06.11.1997, modified by Order 592/2002 published in Monitorul Oficial from 21.10.2002.

25. Mining Industry Strategy in Romania 2008-2020. 
